\title{
Long-Lasting Depolarizations in Mitral Cells of the Rat Olfactory Bulb
}

\author{
Greg C. Carlson, Michael T. Shipley, and Asaf Keller \\ Department of Anatomy and Neurobiology and Program in Neuroscience, University of Maryland School of Medicine, \\ Baltimore, Maryland 21201
}

We investigated the mechanisms of long-lasting depolarizing potentials (LLDs) generated in mitral cells with whole-cell patch recordings in the rat olfactory bulb slice. LLDs occur spontaneously and are evoked by either orthodromic stimulation of the olfactory nerve or antidromic stimulation of mitral and tufted $(\mathrm{M} / \mathrm{T})$ cells. LLDs are followed by a long refractory period, limiting LLD generation to $\sim 1 \mathrm{~Hz}$. LLD production does not appear to involve either intrinsic voltage-activated or metabotropic mechanisms. The initiation of LLDs requires activation of non-NMDA but not NMDA receptors. Dual recordings from the apical dendrites and somata of mitral cells show that LLDs are

The main olfactory bulb receives sensory inputs from olfactory receptor neurons (ORNs) in the nasal olfactory epithelium via the olfactory nerve. Olfactory nerve axons terminate within individual glomeruli, where they synapse directly with the output neurons of the bulb - the mitral and tufted $(\mathrm{M} / \mathrm{T})$ cells — and with juxtaglomerular neurons (see Fig. 1; Shepherd, 1991; Shipley and Ennis, 1996). The olfactory nerve terminals in the glomeruli form the only known excitatory synaptic input to the M/T cells. This input precisely maps ORNs with the same specific odorant receptor to individual glomeruli and therefore to specific groups of M/T cells in the bulb (Vassar et al., 1993; Ressler et al., 1994; Johnson et al., 1998; Rubin and Katz, 1999).

Brief electrical stimulation of the olfactory nerve can produce long-lasting inhibitory and excitatory synaptic potentials in mitral cells (Nowycky et al., 1981; Nickell et al., 1996; Chen and Shepherd, 1997). The inhibition can come from two sources: dendrites of GABAergic juxtaglomerular neurons that synapse with the apical dendritic tufts of mitral cells or dendrites of GABAergic granule cells that synapse with the lateral dendrites of mitral cells (Nicoll, 1971; Shepherd, 1972; Isaacson and Strowbridge, 1998; Schoppa et al., 1998). Both classes of inhibitory neuron receive excitatory inputs from the dendrites of mitral cells, through reciprocal synapses (Rall et al., 1966; Pinching and Powell, 1971; White, 1973; Jahr and Nicoll, 1980; Schoppa et al., 1998).

The source of the prolonged excitatory responses is less certain. Findings that mitral cells express glutamatergic receptors and release glutamate suggest that glutamate released from mitral

\footnotetext{
Received Oct. 14, 1999; revised Dec. 14, 1999; accepted Dec. 17, 1999.

This work was supported in part by US Public Health Service Grants NS-31078 and NS-35360 (A.K.) and NS 36940 and DC-00347 (M.T.S.). We are grateful for critical comments and discussion provided by Drs. B. E. Alger, B. Lyon, and M. Meredith.

Correspondence should be addressed to Dr. Asaf Keller, Department of Anatomy and Neurobiology, University of Maryland School of Medicine, 685 West Baltimore Street, Baltimore, MD 21201. E-mail: akeller@umaryland.edu.

Copyright (C) 2000 Society for Neuroscience $0270-6474 / 00 / 202011-11 \$ 15.00 / 0$
}

generated in the distal portion of the apical dendrite, most likely in the glomerulus. The rising phase of LLDs shows characteristics of polyneuronal input, including a high variability and sensitivity to charge screening. Paired recordings from adjacent mitral cells suggest that LLDs occur synchronously only in cells whose apical dendrites ramify in the same glomerulus. These findings suggest that LLDs involve recurrent, intraglomerular dendrodendritic interactions among $\mathrm{M} / \mathrm{T}$ cells.

Key words: dendrodendritic interactions; glutamate; NMDA; GABA; kainate; GluR5; recurrent excitation cell dendrites may generate a prolonged self-excitation (Trombley and Westbrook, 1990; Bardoni et al., 1996; Ennis et al., 1996). Early evidence supporting this hypothesis was described in pioneering work in turtles (Jahr and Nicoll, 1980). Our aim was to determine whether this putative dendrodendritic mechanism may be involved in generating the long-lasting depolarizations. We present evidence that nonsynaptic interactions among the apical dendritic tufts of $\mathrm{M} / \mathrm{T}$ cells occur in physiological conditions, and that these interactions are involved in the spatiotemporal coordination of activity in mitral cells associated with an individual glomerulus.

A portion of this work has been reported previously in abstract form (Carlson et al., 1997).

\section{MATERIALS AND METHODS}

Wistar rats of each sex, 30-45 d old, were killed by decapitation. The bone overlaying the main olfactory bulb and frontal cortex was removed, and the exposed bulb was flushed with ice-cold artificial CSF (ACSF; composition, in mM: $\mathrm{NaCl} 124, \mathrm{NaHCO}_{3} 25, N, N$-bis[2-hydroxyethyl-2aminoethanesulfonic acid (BES) $5, \mathrm{KCl} 3, \mathrm{MgSO}_{4} 1.3, \mathrm{CaCl}_{2} 2$, glucose $15)$. The bulbs and bone underlying them were removed and placed in ice-cold ACSF. One bulb was then dissected away from the remaining bone and dura and glued to the stage of an oscillating tissue slicer (OTS-4000; Electron Microscope Sciences, Gibbstown, NJ), and 350- to $400-\mu \mathrm{m}$-thick sections were cut parallel to the dorsal surface. Slices were transferred to an interface chamber, perfused with oxygenated nACSF, and maintained at $30^{\circ} \mathrm{C}$ for $1-4 \mathrm{hr}$ before recording.

Recordings were made at room temperature in a submersion-type chamber perfused with ACSF at $1.5-2 \mathrm{ml} / \mathrm{min}$. Electrode placement and cell selection were performed with near-infrared differential interference contrast microscopy (NIR-DIC), using 40 or $60 \times$ water immersion objectives in a fixed-stage, upright microscope (BX50-WI; Olympus Optical, Tokyo, Japan).

Whole-cell voltage- and current-clamp recordings were obtained with an Axon 1D or an Axon 200B amplifier (Axon Instruments, Foster City, CA). Recordings were digitized with an ITC-18 interface (Instrutech, Port Washington, NY) and acquired using PULSE software (HEKA Elektronik) on a Power PC Macintosh computer (Apple, Cupertino, CA). The impedance of patch electrodes was 4-8 $\mathrm{M} \Omega$ for somatic recordings and 7-12 $\mathrm{M} \Omega$ for dendritic recordings. Unless otherwise 


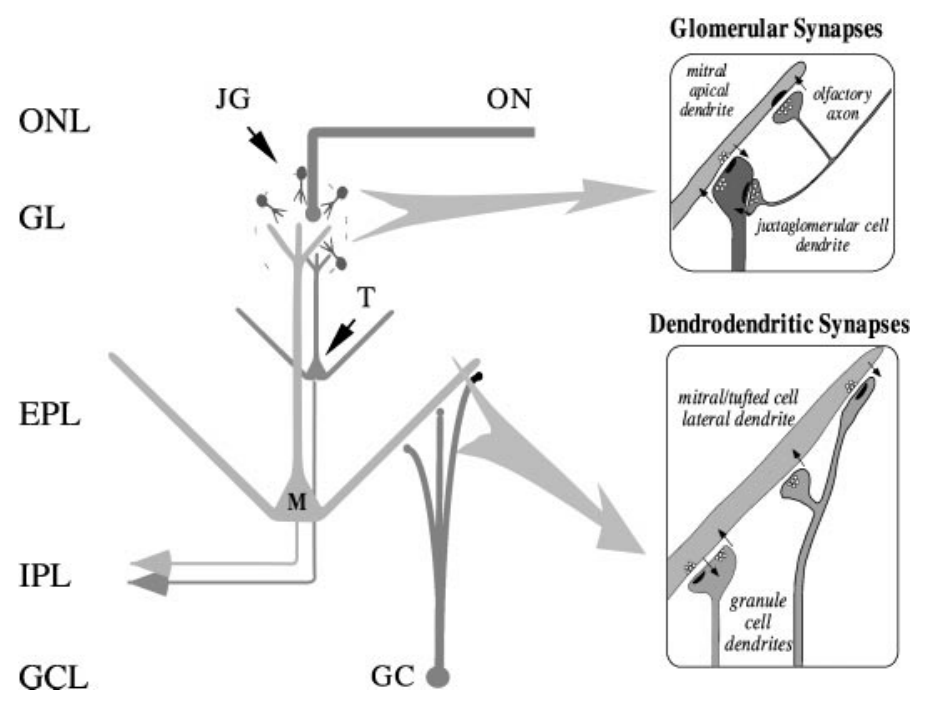

Figure 1. Schematic of the rat olfactory bulb, indicating the different laminae and cell types discussed in the introductory remarks. Olfactory nerve input $(O N)$ forms excitatory synapses (top inset) onto mitral $(M)$, tufted $(T)$, and juxtaglomerular cell $(J G)$ dendrites. M/T cell dendrites form reciprocal dendrodendritic synapses (bottom inset) with GABAergic granule cells $(G C)$. Laminae: $O N L$, olfactory nerve layer; $G L$, glomerular layer; $E P L$, external plexiform layer; $I P L$, internal plexiform layer; $G C L$, granule cell layer.

indicated, current-clamp recordings were made with a $\mathrm{K}^{+}$-gluconatebased intracellular solution (in mM: K-gluconate 120, $\mathrm{KCl} 20$, HEPES 10, $\mathrm{MgCl}^{2}$ 2, ATP-Mg 2, GTP-Tris 0.2, and BAPTA 0.1; $\mathrm{pH}$ was adjusted to 7.3 with $\mathrm{KOH}$ ) and voltage-clamp recordings with $\mathrm{Cs}^{+}$-based solution $\left(\mathrm{CsCH}_{3} \mathrm{SO}_{3} 120, \mathrm{CsOH} 120, \mathrm{HEPES} 10, \mathrm{MgCl} 1\right.$, BAPTA 0.1, ATP·Mg 2.5, and GTP.Tris 0.2 ; $\mathrm{pH}$ was adjusted to 7.3 with $\mathrm{CsOH}$ ). Chemicals for intracellular and extracellular solutions were obtained from Sigma (St. Louis, MO), except QX-314 (Alomone Labs, Jerusalem, Israel). The following pharmacological agents were obtained from Research Biochemicals-Sigma (Natick, MA): 6-cyano-7-nitroquinoxaline-2,3-dione disodium (CNQX), 2-amino-5-phosphonopentanoic acid (AP5), (+)- $\alpha$ methyl-4-carboxyphenylglycine [(+)-MCPG], and (-)-bicuculline methchloride (BIC); LY-293558 was a generous gift from Eli Lilly and Co. (Indianapolis, IN).

Cells with a resting membrane potential more negative than $-50 \mathrm{mV}$ were accepted for analysis. Junction potentials were not compensated. To monitor changes in input resistance, a brief negative pulse was introduced before each stimulus. Extracellular stimulation was through bipolar electrodes made of twisted strands of $25 \mu \mathrm{m}$ nichrome wires (A-M Systems, Everett, WA) with a tip separation of $\sim 50 \mu \mathrm{m}$, using $100-200$ $\mu$ sec constant current pulses of $10-200 \mu \mathrm{A}$.

Cells were filled with biocytin through the recording pipette and fixed overnight in a buffered solution containing either $4 \%$ paraformaldehyde or $1 \%$ paraformaldehyde and $2.5 \%$ glutaraldehyde. To visualize labeled cells with a confocal microscope (FluoView; Olympus), sections were reacted with $0.2 \%$ avidin conjugated to the fluorescent probe Alexa 488 (Molecular Probes, Eugene, OR). For bright-field microscopy, sections were reacted with the ABC Elite kit (Vector Laboratories, Burlingame, CA; $1: 100)$ and DAB $(0.6 \%)$, as previously described (Gottlieb and Keller, 1997). The morphology of labeled cells was reconstructed with the Neurolucida (MicroBrightField, Colchester, VT) morphometry system.

Analyses of recorded waveforms were performed with routines written in Igor (Wavemetrics, Lake Oswego, OR). For statistical comparisons we used an unpaired Student's $t$ test in Excel (Microsoft, Redmond, WA).

\section{RESULTS}

We describe results obtained with whole-cell recordings made from 127 mitral cells in rat olfactory bulb slices. Mitral cells were visualized with NIR-DIC microscopy and identified by the location of their somata in the mitral cell layer and by the large size of their somata and prominent apical dendrites (Price and Powell,
$\mathbf{A}$

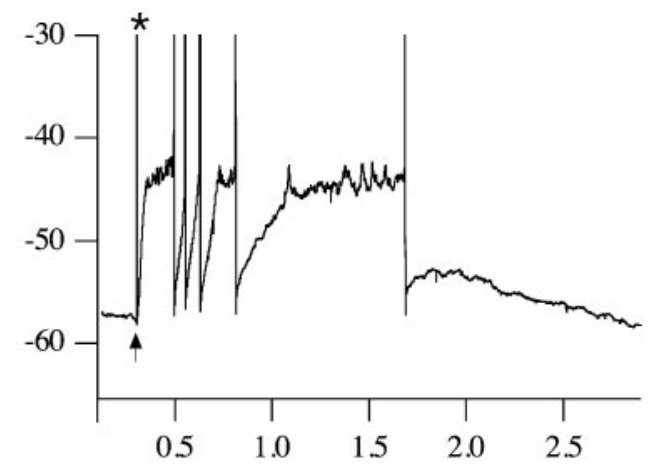

B

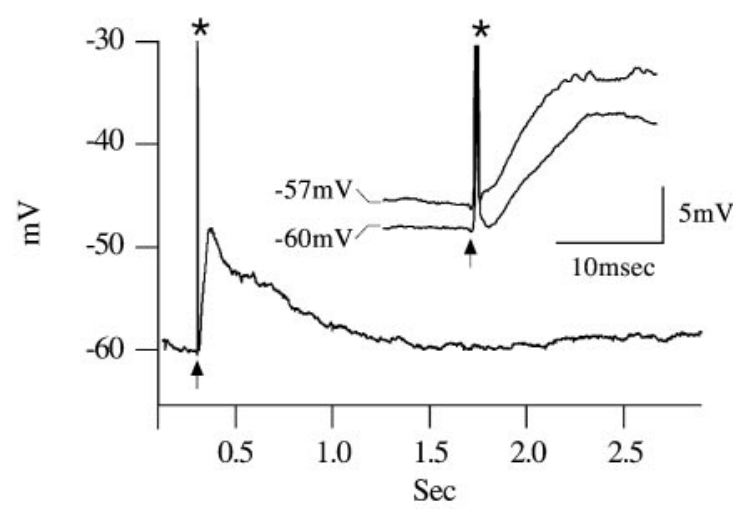

Figure 2. Somatic current-clamp recordings of LLDs evoked by olfactory nerve stimulation, at times indicated by the arrows. Recordings from the same cell were obtained at resting membrane potential $(A)$ and at a slightly hyperpolarized potential $(B)$ to suppress somatic action potentials. The early dendritic prepotential (asterisk) is not suppressed by the hyperpolarization. Inset in $B$, Initial component of the responses shown in $A$ and $B$, depicted to demonstrate the similarity in their kinetics.

1970). In all cases biocytin-labeled cells were subsequently identified in histological sections as mitral cells. We recorded both spontaneous and evoked activity in either voltage-clamp $(n=63)$ or current-clamp $(n=64)$ mode. Evoked activity was generated by orthodromic stimulation of the olfactory nerve above and slightly rostral to the recording site or antidromically by stimulating $\mathrm{M} / \mathrm{T}$ cell axons below and slightly caudal to the recording site.

\section{Evoked long-lasting depolarizations}

A consistent finding in current-clamp recordings was a prolonged depolarizing response to single stimulus pulses to the olfactory nerve layer. These depolarizations could generate bursts of action potentials. (Fig. $2 A$ ). When the cell was hyperpolarized slightly to limit action potential generation, a pronounced depolarization with a slow decay remained (Fig. $2 B$ ). In most cells (26 of 30 recorded in ACSF), these depolarizations had a peak amplitude of $7.4 \pm 0.9 \mathrm{mV}$ and a decay time constant $\left(\tau_{\text {decay }}\right)$ of $347 \pm 49$ msec in cells showing an average membrane time constant of $16 \pm$ $0.2 \mathrm{msec}$. Four cells had a mixture of depolarizing and hyperpolarizing responses, as shown in Figure $4 B$, and these cells were not included in the analysis. In all current-clamp recordings these prolonged responses were depolarizing at resting $\mathrm{V}_{\mathrm{m}}$, and we therefore termed them long-lasting depolarizations (LLDs).

Unless otherwise indicated, all voltage-clamp recordings were performed with QX-314 (10 mM) in the electrode to suppress $\mathrm{Na}^{+}$spikes. In these somatic recordings, mitral cells were held at $-60 \mathrm{mV}$, and LLDs were expressed as long-lasting inward cur- 


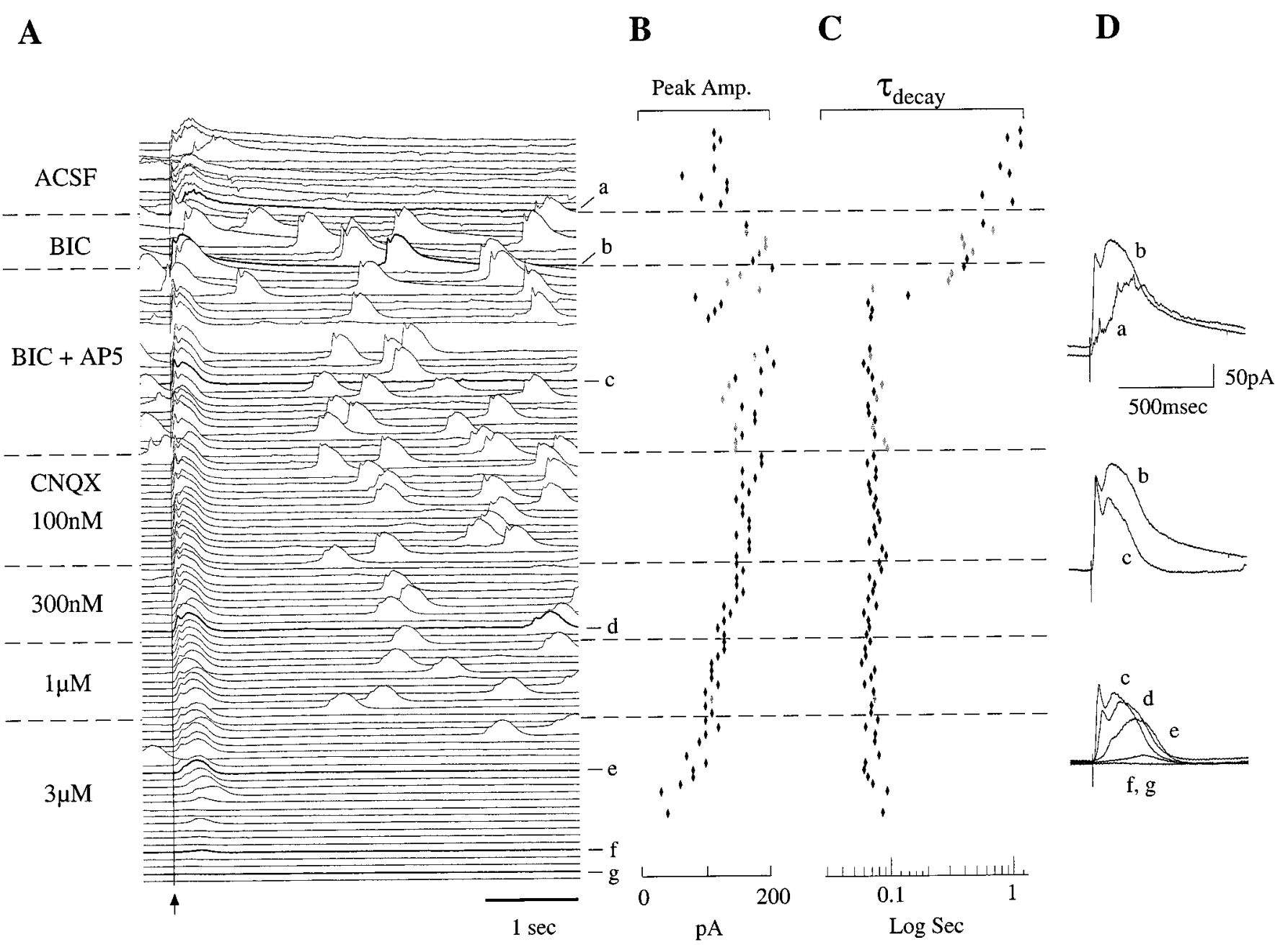

Figure 3. Cascade display of somatic voltage-clamp recordings of olfactory nerve evoked LLDs, showing the effects on LLD kinetics of successive application of BIC $(20 \mu \mathrm{M})$, AP5 $(50 \mu \mathrm{M})$, and CNQX $(0.1$ to $3 \mu \mathrm{M})$. Inward currents are depicted as positive deflections for presentation purposes. $A$, Successive traces recorded at $40 \mathrm{sec}$ intervals; longer periods between traces are represented as wider spacing. The peak amplitude and decay time constant $\left(\tau_{\text {decay }}\right.$ ) of each trace are plotted in $B$ and $C$. Note that although the NMDA receptor antagonist AP5 decreases $\tau_{\text {decay }}$, the expression of LLDs is not dependent on NMDA receptors. The initiation of LLDs is blocked by the non-NMDA antagonist CNQX. Representative traces $(A, a-g)$ are depicted in $D$.

rents (Figs. 3, 4A), with an average peak amplitude of $67.8 \pm 0.9$ $\mathrm{pA}$ and a $\tau_{\text {decay }}$ of $516 \pm 122 \mathrm{msec}(n=22)$. Measurements of peak amplitude were from averages of at least five responses from each cell; measurements of decay time constants were from the final monoexponential tail of the LLDs.

\section{LLDs require AMPA/kainate but not NMDA receptors}

We investigated the neurotransmitter receptors involved in generating LLDs by examining the effects of bath-applied drugs on LLDs evoked by olfactory nerve stimulation (Fig. 3). The $\mathrm{GABA}_{\mathrm{A}}$ receptor antagonist BIC $(20 \mu \mathrm{M})$ significantly increased the amplitude of evoked LLDs $(170 \pm 37 \% ; n=9 ; p=0.035)$. This may reflect suppression of tonic GABAergic inhibition in the olfactory bulb (Aroniadou-Anderjaska et al., 1999a; V. Aroniadou-Anderjaska, F.-M. Zhou, C. A. Priest, M. Ennis, and M. T. Shipley, unpublished results). However, BIC had only a small effect on the decay kinetics of the LLDs (Fig. 3C; $137 \pm$ $74 \%$ of control; $n=9 ; p=0.71$ ).

In some cells ( $n=9$ of 48 recordings in ACSF), LLDs were accompanied by large IPSPs or IPSCs (Fig. 4). These inhibitory responses were suppressed by BIC application $(n=9$ of 9$)$, demonstrating that they are dependent on synaptic activation of $\mathrm{GABA}_{\mathrm{A}}$ receptors and do not arise from intrinsic properties of the mitral cell. In contrast to previous reports (Isaacson and Strowbridge, 1998; Schoppa et al., 1998), we found that these IPSCs persist when NMDA channels are suppressed by the NMDA receptor antagonist AP5 (50 $\mu \mathrm{M}$; Fig. $4 A ; n=4)$.

The contribution of NMDA receptors to LLDs was investigated by applying $50 \mu \mathrm{M}$ AP5 in the presence of BIC (Fig. 3B,C). This caused a decrease in the amplitude of $36 \pm 9 \%$, compared with responses recorded in the presence of BIC, and a decrease in the $\tau_{\text {decay }}$ (by $45 \pm 12 \% ; n=5$ ). However, in all cases, largeamplitude LLDs persisted in the presence of either $50 \mu \mathrm{M}$ AP5 $(n=37$; Figs. $3,4 A)$ or at $100 \mu \mathrm{M}$ AP5 $(n=3)$. In the presence of both AP5 $(50 \mu \mathrm{M})$ and BIC $(20 \mu \mathrm{M})$, the amplitudes of LLDs were $112 \pm 12 \mathrm{pA}$ (voltage clamp; $n=32$ ) and $9.9 \pm 3.4 \mathrm{mV}$ (current clamp; $n=5$ ). This indicates that activation of NMDA receptors is not required to generate LLDs, but these receptors increase their amplitude and prolongs their duration.

In contrast, the AMPA/kainate receptor antagonist CNQX decreased the amplitude of LLDs in a concentration-dependent 


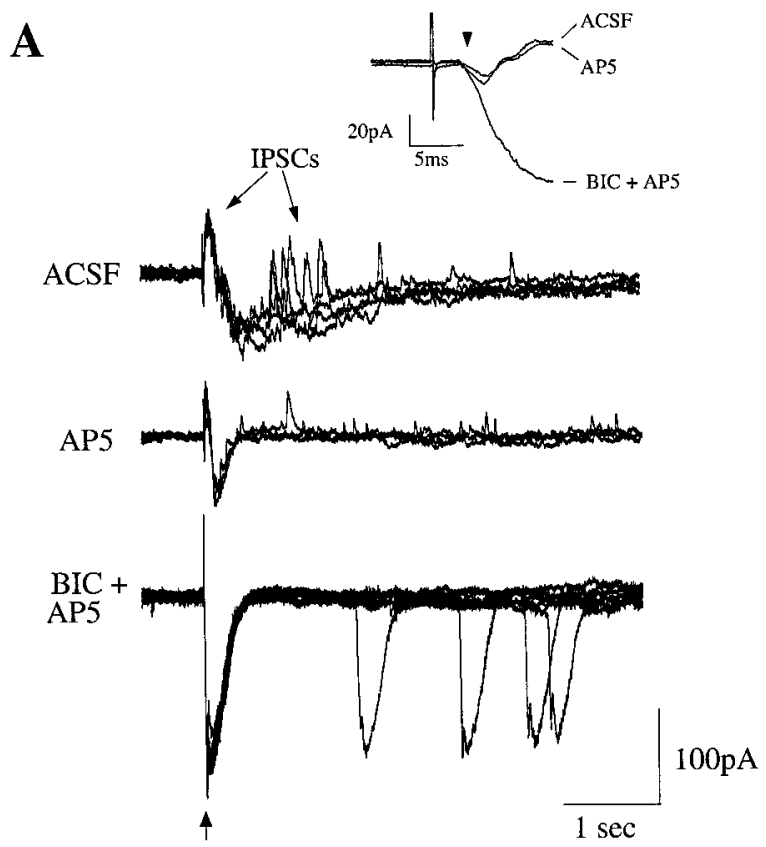

B

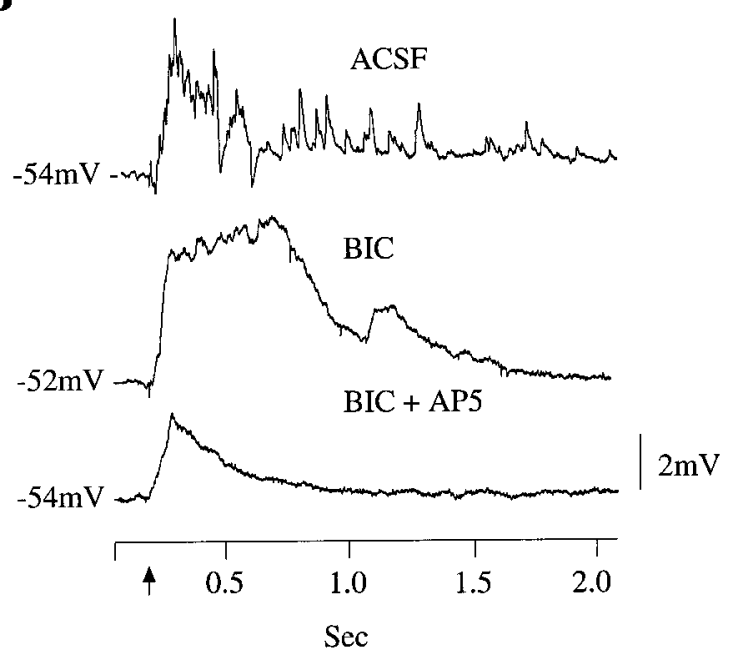

Figure 4. Examples of LLDs showing both depolarizing and hyperpolarizing components. $A$, Eight superimposed somatic voltage-clamp recordings of olfactory nerve-evoked LLDs (at arrow). Large IPSCs occur immediately after the initiation of an LLD, and additional IPSCs coincide with the decay phase of the LLDs. After application of AP5 $(50 \mu \mathrm{M})$, the duration of the LLD decreases, and most of the late IPSCs are suppressed; the short-latency IPSCs are unaffected. Application of BIC $(20 \mu \mathrm{m})$ suppresses the early IPSCs and leads to a large increase in peak LLD amplitudes. Inset, Initial component of the responses, demonstrating that the onset of the LLD (arrowhead) precedes the onset of the early IPSC. Similarly, in current-clamp recordings from another cell $(B)$, IPSPs are suppressed by BIC, producing large, long-duration LLDs. The duration and amplitude of the LLDs are reduced after application of AP5.

manner, with complete suppression occurring in the presence of $3 \mu \mathrm{M}$ CNQX (Fig. $3 A ; n=10$ ). The application of the specific kainate receptor antagonist LY-293558 (10 $\mu \mathrm{M} ; n=3$; Vignes et al., 1997) also completely suppressed olfactory nerve evoked LLDs. Because CNQX can be selective in blocking AMPA receptors in low micromolar concentrations (Paternain et al., 1996), these findings suggest that olfactory nerve-evoked LLDs may involve both AMPA and kainate receptor activity.
$\mathbf{A}$

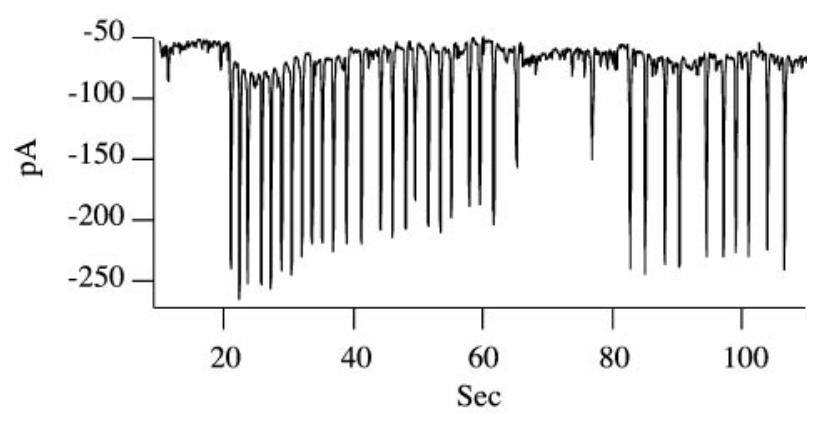

B

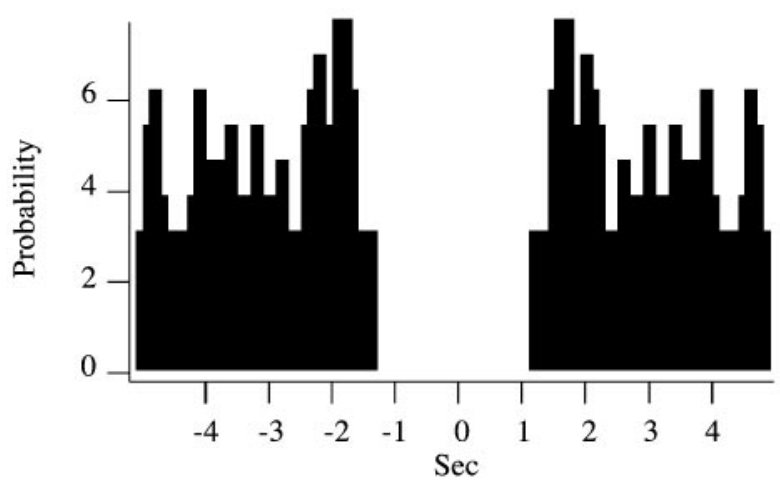

Figure 5. Frequency of spontaneous LLDs, calculated from voltageclamp somatic recordings, in the presence of BIC and AP5. A, A $100 \mathrm{sec}$ epoch of spontaneous LLDs. $B$, Autocorrelogram calculated for spontaneous LLDs recorded from the same cell. Note the long refractory period, indicating that LLDs occur only at intervals $>1.2 \mathrm{sec}$.

A possible role of metabotropic glutamate receptors (mGluRs) in LLD expression was tested by removing GTP from the intracellular solution and replacing it with equimolar concentration $(200 \mu \mathrm{M})$ of the nonhydrolyzable GTP analog guanosine 5-O-(3thiotriphosphate) (GTP- $\gamma-\mathrm{S})$. This had no effect on LLD generation after up to $3 \mathrm{hr}$ of recording $(n=3)$. Similarly, LLDs were unaffected by extracellular application of the mGluR antagonist (+)-MCPG (500 $\mu \mathrm{M} ; n=3)$.

\section{Spontaneous LLDs}

In addition to being evoked by olfactory nerve stimulation, LLDs also occur spontaneously $(n=119)$. The kinetics (amplitude and $\left.\tau_{\text {decay }}\right)$ of spontaneous LLDs were similar to evoked LLDs recorded from the same cell (Figs. 3-6). In all cases, an apparent "refractory period" followed a spontaneous LLD (Figs. 5A, 6E). To quantify this refractory period, we constructed autocorrelograms of spontaneous LLDs (Fig. $5 B$ ). This revealed that there is a period of $1-2 \mathrm{sec}(1.3 \pm 0.1 \mathrm{msec})$ after an LLD in which the probability of a second LLD is nil $(n=5)$. We calculated the frequency of spontaneous LLDs to be $0.2 \pm 0.05 \mathrm{~Hz}$ in the presence of $50 \mu \mathrm{M}$ AP5 and $20 \mu \mathrm{M}$ BIC. Spontaneous LLDs, like evoked LLDs, are also suppressed by CNQX ( $3 \mu \mathrm{M} ; n=10$; Fig. $3 \mathrm{~A})$. In addition, both spontaneous and evoked LLDs are blocked by the $\mathrm{Na}^{+}$channel antagonist tetrodotoxin (TTX; $1 \mu \mathrm{M} ; n=4$ ) and as well as the removal of $\mathrm{Ca}^{2+}$ from the extracellular solution $(n=2)$. The similar pharmacology and kinetics of spontaneous and evoked LLDs suggest that both are generated by the same mechanisms. 
$\mathbf{A}$

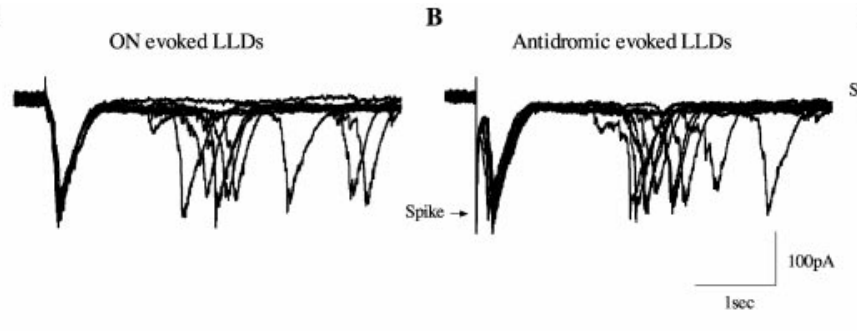

$\mathbf{E}$

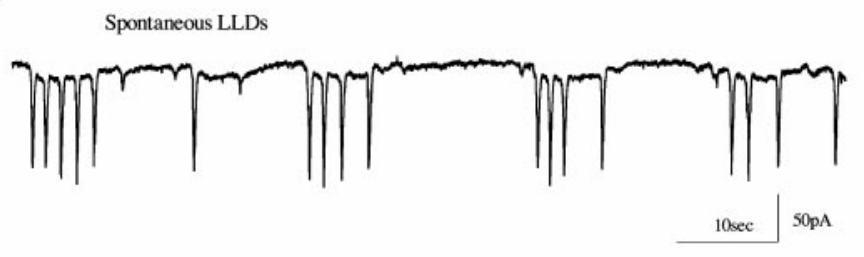

C

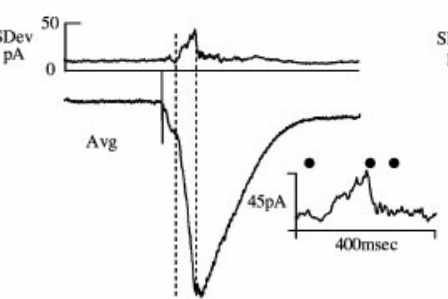

F

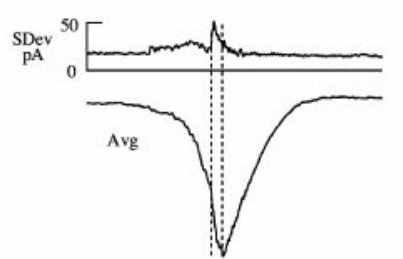

D

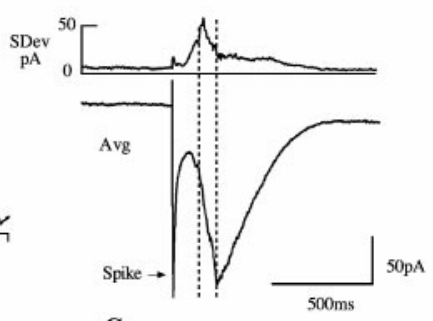

G

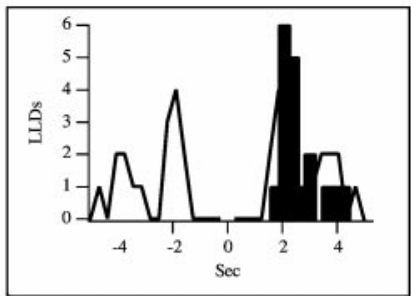

Figure 6. Somatic voltage-clamp recordings from a single mitral cell, depicting responses to orthodromic stimulation of the olfactory nerve $(A)$, antidromic stimulation below the mitral cell layer $(B)$, and spontaneous LLDs $(E)$. Antidromic and orthodromic stimulation evoke highly reproducible and nearly identical LLDs (compare $A, B$ ). This is consistent with LLDs being generated by interactions among M/T cells. In this cell, recorded without QX-314, antidromically evoked LLDs are preceded by an antidromic spike $(B)$. To quantify the variance of the evoked LLDs, we plotted the SDs (SDev) of the averaged traces $(C, D)$. The largest variance occurs during the late component of the rising phase of the LLDs (delineated by the vertical dashed lines). This is also consistent with the hypothesis that LLDs are generated by multiple interactions among $\mathrm{M} / \mathrm{T}$ cells. The plot in $C$ is shown at higher magnification in the inset. Filled circles correspond to the time points used in the text to represent the group variance data (at 20 msec after stimulus, the peak of the SD, and the peak of the LLD). F, Averaged spontaneous LLDs and their variance obtained from the traces depicted in $E$. Individual traces were aligned relative to the onset of their fastest component ( $F$, first vertical dashed line); as in the evoked LLDs, variability is largest before the peak. $G$, Autocorrelogram of spontaneous LLDs (thick line) and peristimulus histogram (bars) of evoked LLDs (excluding the initial LLD) shows the similar refractory period for both spontaneous and evoked responses.

\section{Voltage dependence of LLDs}

In voltage-clamp somatic recordings, we tested the voltage dependence of LLDs by measuring peak amplitude versus holding potentials ranging from -100 to $-30 \mathrm{mV}$. It was not possible to apply voltage commands more positive than $-30 \mathrm{mV}$, because this resulted in the generation of $\mathrm{Na}^{+}$or $\mathrm{Ca}^{2+}$ spikes. These $I-V$ relationships were linear, and extrapolation of these plots revealed that the reversal potential of LLDs was $52 \pm 45 \mathrm{mV}(n=$ 7). These values are inconclusive, because space-clamp limitations may not have allowed for reliable control of membrane voltage at the site of LLD generation. Nevertheless, LLD amplitude increased at more hyperpolarized holding potentials. This is consistent with the conclusion that LLDs are generated by an inward current showing a depolarized reversal potential. Furthermore, these results are inconsistent with LLDs being produced by intrinsic, voltage-activated membrane properties.

\section{Auto- or recurrent excitation?}

In $0 \mathrm{Mg}^{2+}$ conditions, glutamate released from the dendrites of $\mathrm{M} / \mathrm{T}$ cells diffuses to and activates glutamate receptors on the dendrite of the parent or neighboring $\mathrm{M} / \mathrm{T}$ cells, producing depolarization (Jahr and Nicoll, 1980; Aroniadou-Anderjaska et al., 1999b; Isaacson, 1999). To investigate whether LLDs are generated by a similar autoexcitation mechanism in ACSF, we attempted to generate LLDs with depolarizing current pulses (10$100 \mathrm{msec}$ to $\sim 0 \mathrm{mV} ; n=30$ ), or voltage commands $(10-100 \mathrm{msec}$ up to $30 \mathrm{mV} ; n=32)$ through either dendritic $(n=3)$ or somatic $(n=32)$ patch pipettes. These procedures evoked $\mathrm{Na}^{+}$or Ca $^{2+}$ spikes but never produced an LLD.

To further test the autoexcitation hypothesis, we attempted to suppress synaptic release of glutamate from the recorded cell by intracellularly dialyzing them with the $\mathrm{Ca}^{2+}$ chelator BAPTA (5
mM; $n=3$ ). BAPTA had no effect on the occurrence of LLDs after $2 \mathrm{hr}$ of recording. We conclude that in the presence of normal $\mathrm{Mg}^{2+}$ concentrations, a single mitral cell does not generate LLDs through autoexcitation.

We reasoned that if a single mitral cell cannot generate LLDs, recurrent excitation among $\mathrm{M} / \mathrm{T}$ cell dendrites might be required. To test this recurrent excitation hypothesis we used antidromic stimulation to simultaneously activate a population of $\mathrm{M} / \mathrm{T}$ cells (Fig. 6). To limit input from GABAergic granule cells, these experiments were performed in $20 \mu \mathrm{M}$ BIC. Antidromic stimulation produced LLDs in most mitral cells ( $n=13$ of 15). Because $\mathrm{M} / \mathrm{T}$ cells do not interact with each other via axon collaterals, this suggests that recurrent interactions among $\mathrm{M} / \mathrm{T}$ dendrites can trigger LLDs. Antidromically evoked LLDs were indistinguishable from those evoked by olfactory nerve stimulation: they had similar waveforms (amplitude, $84 \pm 17 \mathrm{pA} ; \tau_{\text {decay, }} 329 \pm 90 \mathrm{msec}$; Fig. 6), and they were suppressed by CNQX $(3 \mu \mathrm{M} ; n=4)$, LY-293558 (10 $\mu \mathrm{M} ; n=2)$, and TTX $(1 \mu \mathrm{M} ; n=4)$.

\section{LLDs are caused by the recruitment of multiple excitatory inputs}

The similarity in the kinetics and the pharmacology of both antidromically and orthodromically evoked LLDs suggests that they are mediated by a common mechanism. This mechanism most likely involves glutamate release from a population of $\mathrm{M} / \mathrm{T}$ cells. Consistent with this is the fact that LLDs occurred when the cell was internally perfused with QX-314 but not when TTX was added to the bath. Further consistent with this was the observation that LLDs typically have multiple inflection points during their rising phase, suggestive of multiple components (Fig. $7 A$ ). One possibility is that olfactory nerve stimulation activates a population of bulbar excitatory interneurons, which relay polysyn- 
A

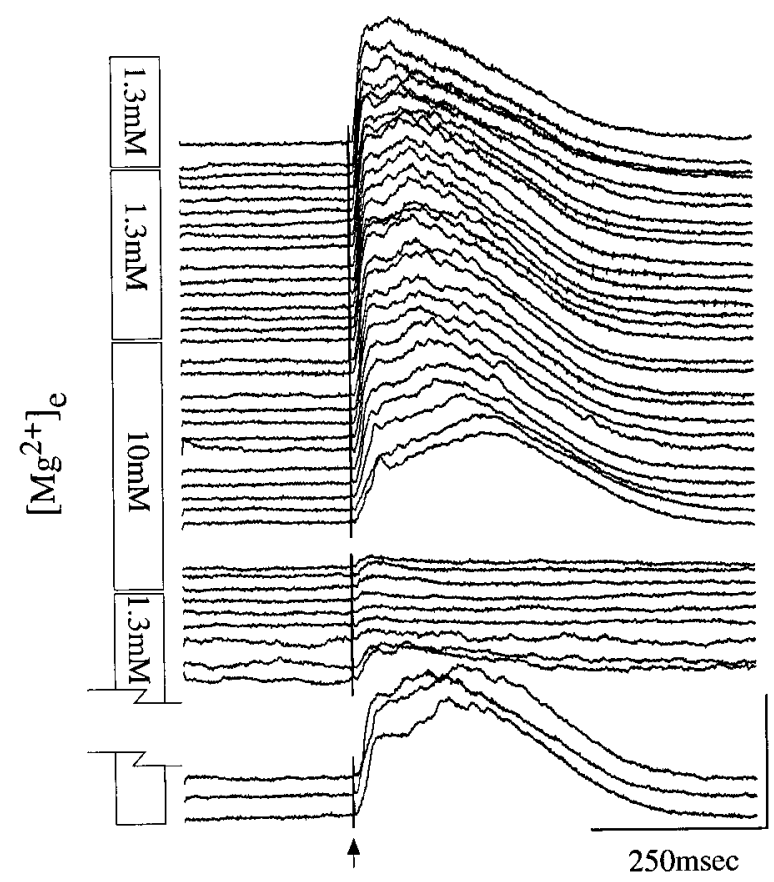

B

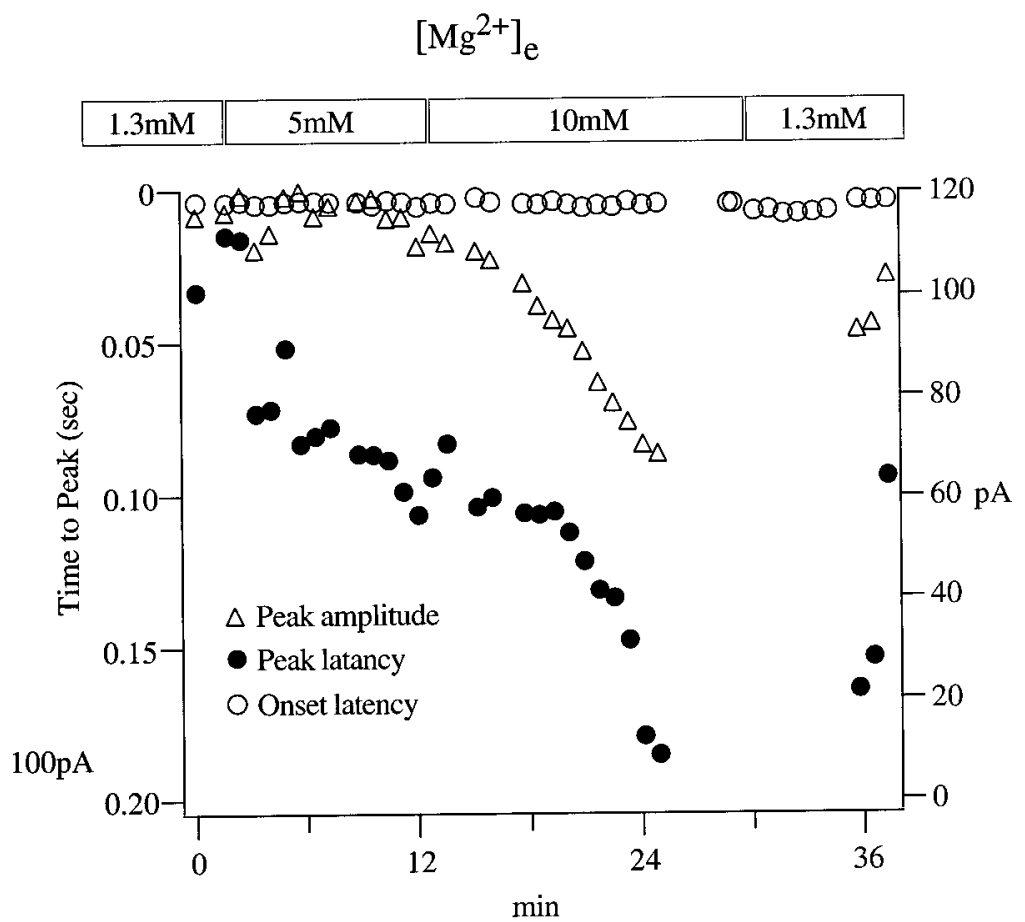

Figure 7. A, Voltage-clamp somatic recordings (traces inverted), depicting the effect of increasing the extracellular concentration of Mg ${ }^{2+}$ on LLDs evoked by olfactory nerve stimulation. B, Peak latency ( filled circles), amplitude (open triangles), and onset latency (open circles). Charge-screening by increased $\left[\mathrm{Mg}^{2+}\right]_{\mathrm{e}}$ results first in an increase in peak latency, followed by a decrease in amplitude, with little effect on the onset latency of the LLDs.

aptic inputs to the mitral cells. However, there is no evidence for such cells. A more likely possibility is that olfactory nerve inputs activate a population of $\mathrm{M} / \mathrm{T}$ cells, and that recurrent excitatory interactions among the dendrites of these cells generate LLDs.

A characteristic of recurrent excitatory responses is betweentrial variability in amplitude or onset latency, which increases with the number of neurons involved in generating the response (Gil and Amitai, 1996). Therefore, if LLDs reflect recurrent excitation, they should exhibit intertrial variability. To investigate this, we calculated the SD of the amplitude of olfactory nerveevoked LLDs, recorded at 40-90 sec intervals. In all cells $(n=$ 14 ), amplitude variability was low both in the early phase of the response (8.4 $\pm 5.0 \mathrm{pA}$ at $20 \mathrm{msec}$ after stimulus) and at the peak of the LLD $(8.8 \pm 6.0 \mathrm{pA}$; see Fig. $6 C$, inset $)$. In contrast, in all cases amplitude variability was largest $(32.2 \pm 9.7 \mathrm{pA}$ relative to baseline) during the late part of the rising phase of the LLD (Fig. $6 C)$. The relative invariance in the early phase indicates that LLDs are initiated by a monosynaptic mechanism, namely by olfactory nerve inputs. The large variability in the rising phase is consistent with generation of LLDs by dendrodendritic recurrent excitation. The decrease in variance at the peak of the LLD suggests that a consistent number of dendritic elements are recruited after the initiation of the LLDs, although LLDs could also be limited by another mechanism such as desensitization of glutamatergic receptors.

\section{LLDs are sensitive to charge screening}

To further test the hypothesis that LLDs result from recurrent dendrodendritic excitation, we decreased synaptic efficacy and excitability by gradually increasing the extracellular $\mathrm{Mg}^{2+}$ concentration while maintaining $\mathrm{Ca}^{2+}$ at $2 \mathrm{~mm}$. High extracellular
$\mathrm{Mg}^{2+}$ increases the threshold for action potential generation by a charge-screening effect (Berry and Pentreath, 1976). This should have little influence on the olfactory nerve evoked responses, which are generated by direct, suprathreshold olfactory nerve stimulation (Berry and Pentreath, 1976). In contrast, charge screening should progressively increase the latency of the recurrent dendrodendritic interactions, with a concomitant decrease in the LLD peak. Indeed, increasing extracellular $\mathrm{Mg}^{2+}$ caused a reversible, dose-dependent reduction in the amplitudes of LLDs, with complete suppression at $10 \mathrm{mM} \mathrm{Mg}^{2+}(n=3$; Fig. 7). As high concentrations of $\mathrm{Mg}^{2+}$ were washed in, there was initially a progressive delay in the latency to peak amplitude. This was followed by a decrease in peak amplitude. However, the initial phase of the LLDs mediated by olfactory nerve inputs persisted (Fig. 7B). These findings are consistent with the hypothesis that LLDs are initiated by ON synaptic input and amplified by recurrent, dendrodendritic excitatory interactions.

\section{Are LLDs graded or all-or-none?}

Monosynaptic inputs are expected to produce a graded response, whose amplitude is proportional to the intensity of the synaptic input. In contrast, regenerative mechanisms involving recurrent excitatory interactions typically produce an all-or-none response (Traub and Wong, 1982). Thus, if LLDs are generated solely by olfactory nerve synaptic input, it should be possible to produce graded LLDs by varying the strength of these inputs. We investigated the relationship between the intensity of olfactory nerve stimulation and the amplitudes of LLDs (Fig. 8). Stimulus intensities slightly above threshold (producing failures in $40-60 \%$ of the trials) generated LLDs whose amplitudes were nearly identical to those produced by stimulus intensities that were up to four 
A

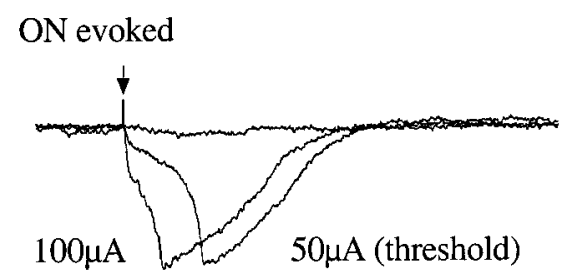

Spontaneous
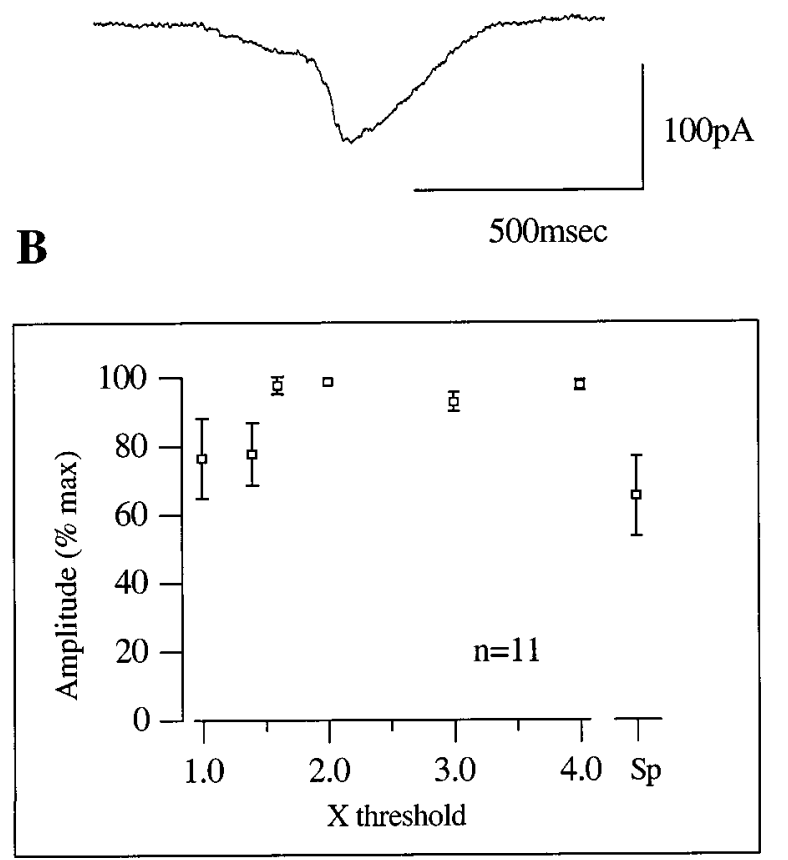

Figure 8. Varying the stimulus intensity to the olfactory nerve has little effect on the magnitude of evoked LLDs. $A$, Somatic voltage-clamp recordings of LLDs evoked at threshold (producing 40-60\% failures) and twice-threshold stimulation intensities and a spontaneous LLD recorded from the same cell. $B$, Plots relating the amplitude of LLDs and stimulus intensities (relative to thresholds). Sp, Amplitude of spontaneous LLDs.

times higher than threshold (Fig. $8 ; n=11$ cells). Furthermore, the amplitudes of evoked LLDs were similar to the spontaneous LLDs (Fig. 8B). This finding indicates that olfactory nerveevoked LLDs are generated in an all-or-none manner and is consistent with the operation of a regenerative mechanism, rather than monosynaptic transmission from the olfactory nerve.

\section{Site of LLD induction}

Our recurrent excitation hypothesis states that LLDs are triggered by olfactory nerve input but are amplified by local excitatory interactions among the intraglomerular tufts of $\mathrm{M} / \mathrm{T}$ cells. This implies that LLDs are generated in the apical dendrites and then propagated to the soma. If this is true, then the onset latency of an LLD recorded in the dendrite should be shorter than that recorded in the soma. To test this prediction, we performed simultaneous recordings from the soma and distal apical dendrite of the same mitral cell (Fig. 9; $n=3$ cells) and measured the latency of olfactory nerve evoked LLDs. Every LLD recorded occurred first in the dendrites $(\Delta T=0.5 \pm 0.1 \mathrm{msec})$, had a faster peak rise time $(34 \pm 22 \%)$ and a larger amplitude $(0.7 \pm 0.1 \%)$ than the same LLD recorded in the soma. This demonstrates that
A
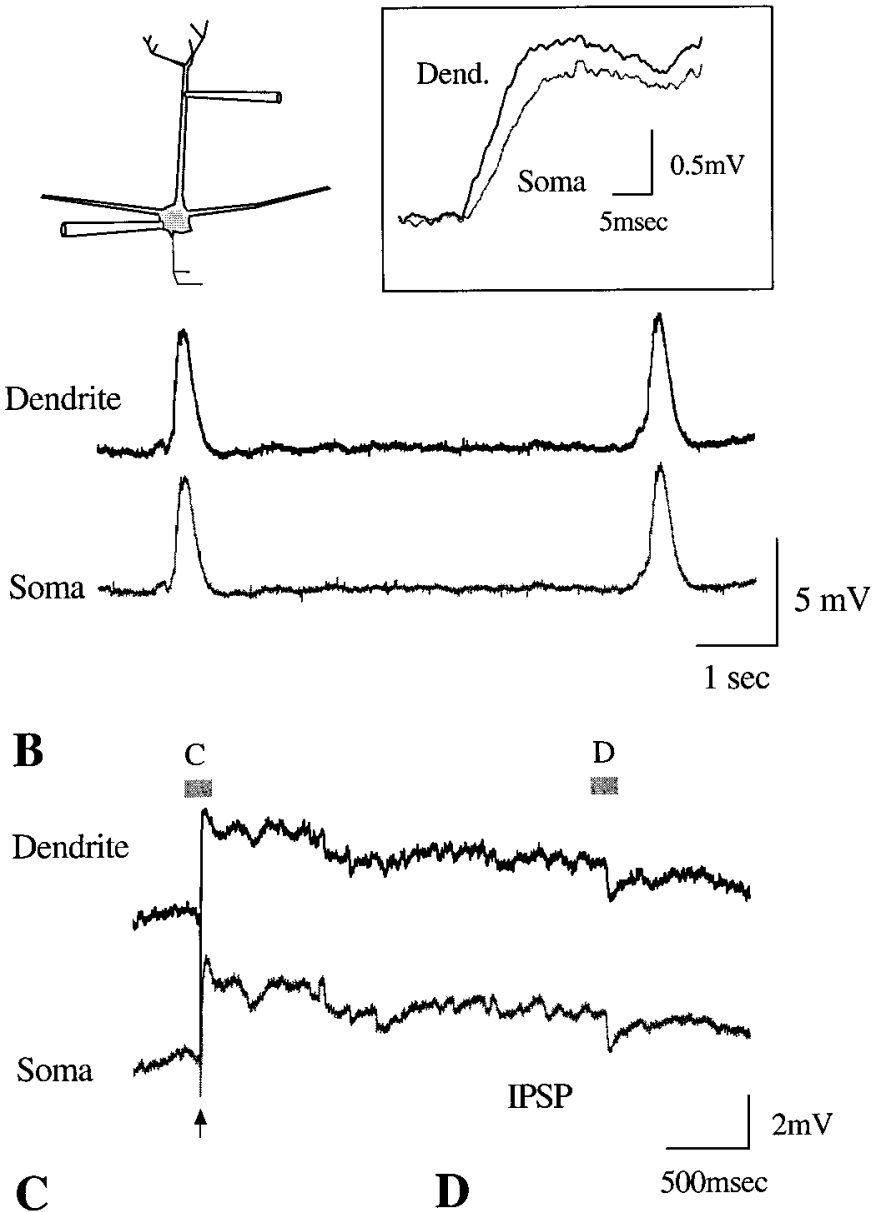

C
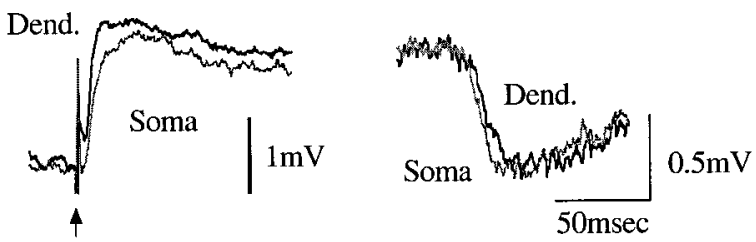

Figure 9. Dual recordings locate LLD generation to the distal portion of the apical dendrite. $A$, Simultaneous current-clamp recordings of spontaneous LLDs from the soma and apical dendrite of the same mitral cell (schematic) in the presence of BIC and AP5. The inset shows that the LLD is recorded first in the dendrite, and that the rise time of the LLD is faster in the dendritic recording. $B$, Simultaneous current-clamp recordings of evoked LLDs from the soma and apical dendrite of another mitral cell. Shaded bars labeled $C$ and $D$ indicate areas shown at a shorter time scale in the corresponding panels below. $C$, The rise time of the LLD is faster in the dendrite. $D$, In contrast, the IPSP is recorded first through the somatic electrode.

LLDs are initiated in the intraglomerular dendritic tuft and are propagated to the soma. In contrast, IPSPs appeared first at the somatic electrode before propagating to the dendritic recording site (see Fig. 9D), suggesting that these IPSPs were generated at the soma or lateral dendrites.

\section{LLDs are generated in a single glomerulus}

The apical dendritic tufts of $\mathrm{M} / \mathrm{T}$ cells are restricted to a single glomerulus (Cajal, 1995). Therefore, if LLDs are generated by recurrent excitatory interactions among these dendritic tufts, 


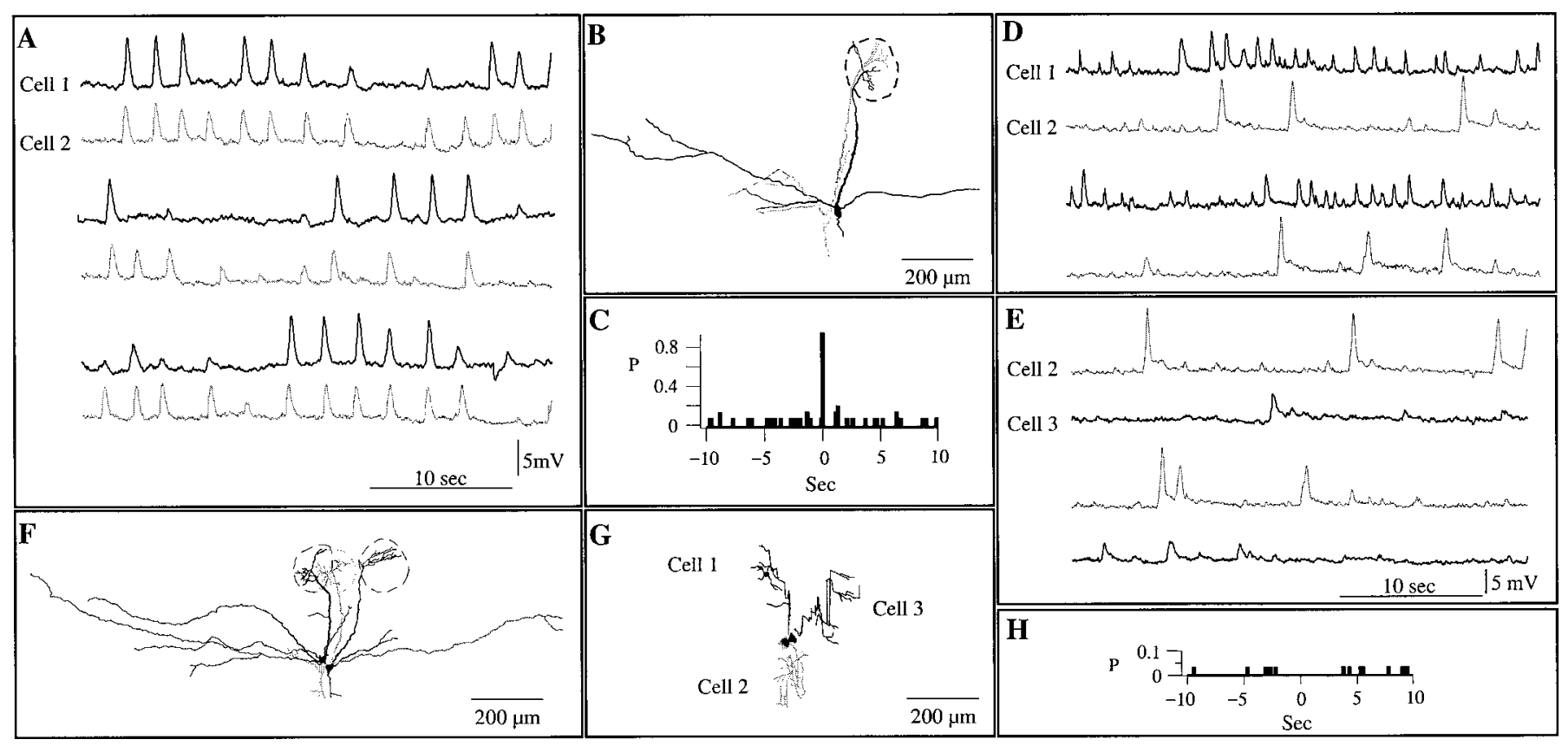

Figure 10. Paired current-clamp recordings of spontaneous activity from the somata of mitral cells. $A$, Simultaneous recordings showing synchronous LLDs from cells sharing the same glomerulus. $B$, Drawing of the cells recorded in $A$, with glomerulus indicated by the dashed line. Designation of the cells corresponds to their representative traces in $A$ (cell 1, black; cell 2, gray) $C$, Cross-correlogram calculated from 5 min of paired recording showing synchronized LLDs. $D, E$, In contrast, simultaneous recordings from three cells whose dendrites project to different glomeruli display asynchronous LLD activity. $F$, Drawing of cells recorded from in $D$ and $E$. $G$, Drawing of the cells shown in $F$, rotated $90^{\circ}$, i.e., as viewed from the surface of the bulb, demonstrating that each dendritic tuft ramifies in a different glomerulus. $H$, Cross-correlogram from 5 min of paired recording from cells projecting to different glomeruli.

LLDs recorded from a pair of cells whose dendrites project to the same glomerulus should be correlated. In contrast, if LLDs represent activity that propagates throughout the olfactory bulb, $\mathrm{M} / \mathrm{T}$ cells associated with different glomeruli should display correlated LLDs (Traub and Wong, 1982; Haberly and Sutula, 1992). To test these possibilities, we obtained simultaneous currentclamp recordings from 18 pairs of mitral cells.

In 16 of 18 pairs there was no temporal correlation in the occurrence of spontaneous LLDs (Fig. 10D,E,H). None of these noncorrelated pairs projected to the same glomerulus (Fig. $10 F, G)$. In contrast, the two pairs of cells that projected to the same glomerulus (Fig. 10B) displayed highly correlated LLDs (correlation coefficient $=0.81$ and 0.86 ; Fig. $10 \mathrm{~A}-\mathrm{C}$ ). This indicates that LLDs are generated in individual glomeruli and synchronize the activities of the $\mathrm{M} / \mathrm{T}$ cells associated with that glomerulus.

\section{DISCUSSION}

\section{Mechanisms of LLD expression}

Our findings demonstrate that mitral cells in the adult rat olfactory bulb express long-lasting ( $>400 \mathrm{msec})$ depolarizations $(\sim 7$ $\mathrm{mV}$ ) that occur spontaneously, in response to olfactory nerve stimulation and after antidromic activation of $\mathrm{M} / \mathrm{T}$ cells. The initiation of LLDs requires activation of non-NMDA ionotropic glutamate receptors. The expression of LLDs appears to result from recurrent interactions among the apical intraglomerular dendrites of $\mathrm{M} / \mathrm{T}$ cells.

This hypothesis is supported by the following evidence:

(1) Non-NMDA receptor-dependent LLDs can be evoked by antidromic stimulation of $\mathrm{M} / \mathrm{T}$ cells, suggesting that glutamate release from $\mathrm{M} / \mathrm{T}$ dendrites is sufficient to produce LLDs.
(2) LLDs consist of both NMDA and non-NMDA receptormediated components. The unusually long duration of both components is consistent with prolonged glutamatergic input generating the LLD.

(3) LLDs persist with intracellular QX-314, which blocks intrinsic voltage-dependent $\mathrm{Na}^{+}$channels, but are blocked by bath application of TTX, suggesting that activity of other neurons is necessary for generating LLDs. Consistent with this interpretation, removal of extracellular $\mathrm{Ca}^{2+}$ also blocks LLDs.

(4) The presence of multiple inflection points during the rising phase of the LLDs and the large intertrial variability in the rising phase of LLDs are consistent with the action of multiple excitatory components. Increasing spike threshold by charge screening retards and represses these components as well as the peak amplitude of LLDs, further supporting the idea that LLDs are made up of multiple excitatory inputs.

(5) Dual recordings from the soma and apical dendrite of a mitral cell demonstrate that LLDs are initiated in the distal portion of the apical dendrites, which is consistent with the idea that LLDs are generated by intraglomerular dendrodendritic interactions.

Militating against LLDs being generated by intrinsic membrane properties or a metabotropic mechanism are the following findings:

(1) LLDs cannot be evoked by current pulses or depolarizing voltage steps and are present in QX-314, which blocks voltageactivated $\mathrm{Na}^{+}$channels; therefore LLDs are not likely to be evoked by a purely voltage-activated mechanism.

(2) LLD generation is insensitive to hyperpolarization.

(3) Slow potentials associated with activation of metabotropic receptors are predominately dependent on modulation of $\mathrm{K}^{+}$ 
channels or changes in intracellular $\mathrm{Ca}^{2+}$ concentrations (Pitler and Alger, 1990; Crépel et al., 1994; Greene et al., 1994). Thus, the persistence of LLDs in the presence of $\mathrm{Cs}^{+}$-containing intracellular solutions and high intracellular $\mathrm{Ca}^{2+}$ buffering argues against a metabotropic mechanism for LLD expression. Consistent with this, LLDs persist, without decrement, in the presence of the metabotropic glutamate antagonist MCPG.

\section{Role of NMDA receptors}

We recently reported that under conditions that favor NMDA receptor activation (i.e., reduced extracellular $\mathrm{Mg}^{2+}$ ), mitral cells can excite themselves (autoexcitation; also see Nicoll and Jahr, 1982) or adjacent $\mathrm{M} / \mathrm{T}$ cells (recurrent excitation) via dendrodendritic interactions (Aroniadou-Anderjaska et al., 1999b). A similar finding was reported independently by Isaacson (1999). These NMDA-dependent responses differ from the LLDs reported in the present study in two important respects: first, LLDs are not dependent on activation of NMDA receptors and occur in physiological concentrations of $\mathrm{Mg}^{2+}$; and second, whereas LLDs are the result of interactions among the apical dendritic tufts of $\mathrm{M} / \mathrm{T}$ cells in a single glomerulus, the NMDA-dependent responses appear to involve, as well, interactions among the lateral dendrites of mitral cells in the external plexiform layer.

Although LLD generation is not dependent on NMDA receptors, LLDs do have a prominent NMDA component, which significantly enhances their amplitude and duration. This may prolong output from mitral cells, particularly through dendritic synapses formed between the mitral cell lateral dendrites and granule cells (Isaacson and Strowbridge, 1998; Schoppa et al., 1998).

\section{Anatomical substrates for LLDs}

The hypothesis that LLDs are generated by excitatory interactions among the apical dendrites of $\mathrm{M} / \mathrm{T}$ cells is seemingly at odds with the fact that there are no conventional anatomical synapses between these cells (Pinching and Powell, 1971; White, 1973; Kosaka et al., 1997). However, NMDA-dependent interactions among the lateral dendrites of mitral cells do occur in the absence of anatomical synapses (Aroniadou-Anderjaska et al., 1999b), via spillover from dendritic release sites (Bergles et al., 1999).

Recent data suggest the existence of neuroanatomical correlates for nonsynaptic interactions in the glomeruli. The apical dendritic tufts of $\mathrm{M} / \mathrm{T}$ cells branch profusely within a glomerulus, forming bundles with the dendrites of other M/T cells (Kasowski et al., 1999). These dendritic bundles are wrapped in a glial sheath, which may slow the diffusion of glutamate from the apical tufts (Kasowski et al., 1999). The dendrites forming these bundles have also been shown to express both NMDA and non-NMDA glutamate receptors, including the kainate receptor subtypes GluR5/6 (Montague and Greer, 1999).

This anatomical arrangement suggests that glutamate released from the apical dendrites of $\mathrm{M} / \mathrm{T}$ cells results in a prolonged elevation of local extracellular glutamate. This extrasynaptic glutamate recurrently activates groups of neighboring apical dendritic tufts associated with that glomerulus. This is consistent with the all-or-none and multicomponent nature of LLDs and the observation that LLDs are initiated in the apical dendrite and propagate secondarily to the soma. Because the GluR5-specific antagonist LY-293558 blocks LLDs, it is likely that LLDs involve the activation of kainate receptors.

Each dendritic bundle is associated with a single glomerulus (Kasowski et al., 1999); thus LLDs are expected to occur in synchrony in cells whose apical dendrites ramify in the same glomerulus. This prediction is supported by our present findings (Fig. 10). Mitral cells associated with the same glomerulus have synchronous LLDs. Mitral cells ramifying in different glomeruli have uncorrelated LLDs. This is true even for mitral cells whose somata are adjacent to each other but whose dendrites terminate in different glomeruli (Fig. 10; Buonviso et al., 1991). Our sample size of simultaneously recorded mitral cells associated with the same glomerulus is small, attributable in part to the fact that an individual glomerulus contains apical dendrites of only 15-20 mitral cells (Allison and Warwick, 1949; Buonviso et al., 1991), and this number is even smaller in the relatively thin portion of the slices available in the present study.

\section{Physiological substrates for LLDs}

Our data and the anatomical considerations discussed above suggest that LLDs involve extrasynaptic release of glutamate from $\mathrm{M} / \mathrm{T}$ dendrites. This hypothesis is supported by reports of extrasynaptic transmitter release from dendrites in other types of neurons (Cheramy et al., 1981; Glitsch et al., 1996; Morishita et al., 1998). Glutamate release from $\mathrm{M} / \mathrm{T}$ dendrites may be evoked by action potentials initiated in the apical dendrites (Mori and Takagi, 1975; Chen et al., 1997). Alternatively, dendritic release of glutamate may require back-propagation of action potentials initiated at the soma (Chen et al., 1997).

We do not know whether mitral or tufted cells are the principal source of glutamatergic input generating the LLDs. Tufted cells significantly outnumber mitral cells (Allison and Warwick, 1949; Meisami and Safari, 1981). Moreover, tufted cells tend to fire bursts of action potentials (Heyward et al., 1999) and thus may be favorable for sustaining the LLDs.

\section{LLDs and inhibition}

Previous studies reported that activation of reciprocal synapses between mitral and granule cells is NMDA receptor-dependent, such that GABAergic inputs from granule to mitral cells occur only if glutamate released from mitral cells activates NMDA receptors on granule cells (Isaacson and Strowbridge, 1998; Schoppa et al., 1998). In contrast, we recorded IPSCs in normal $\mathrm{Mg}^{2+}$ concentrations and in the presence of AP5 (Fig. 4). This finding may be explained by the idea that LLDs reflect synchronous activation of a number of $\mathrm{M} / \mathrm{T}$ cells, which generate sufficient non-NMDA excitatory input to granule cells to evoke GABA release from these neurons. Pertinent is a finding by Schoppa et al. (1998) that the firing of an individual mitral cell does not generate a reciprocal IPSP. Thus, inhibition through granule cells may be tuned to respond to the synchronous activation of several $\mathrm{M} / \mathrm{T}$ cells, and this synchrony is provided by LLDs. This interaction may be strongly modulated by the activation of NMDA receptors, both on granule cells (Isaacson and Strowbridge, 1998; Schoppa et al., 1998) and on the lateral dendrites of M/T cells (Aroniadou-Anderjaska et al., 1999b).

We have previously shown that GABA released from periglomerular neurons exerts potent presynaptic inhibition on ON terminals, and that this inhibition results in paired pulse depression of responses to repetitive ON inputs (Nickell et al., 1994; Keller et al., 1998; Aroniadou-Anderjaska, Zhou, Priest, Ennis, and Shipley, unpublished results). The synchronous activation of $\mathrm{M} / \mathrm{T}$ cells during an LLD may enhance activation of periglomerular neurons via dendrodendritic synapses (see Fig. 1). This, in turn, is likely to augment the presynaptic inhibition of ON terminals, thus further suppressing responses to repetitive ON inputs. Thus, one 
consequence of LLDs may be to convert a prolonged $\mathrm{ON}$ input into a phasic postsynaptic response.

\section{LLDs and odor processing}

We stress that we have not yet determined whether LLDs occur in vivo in response to odorant stimulation. However, LLDs are reminiscent of previously reported responses to odors. Odorant stimulation produces slow field potentials in turtle (Beuerman, 1975), frog (Ottoson, 1959), and rabbit olfactory bulb (Ottoson, 1956). Imaging of voltage-dependent dye signals from salamander olfactory bulb produces prolonged periods of excitation in specific glomeruli (Cinelli and Salzberg, 1992; Cinelli et al., 1995).

Olfactory receptor neurons expressing the same odorant receptor (a cohort) project to two (or a few) topographically fixed glomeruli in the olfactory bulb (Vassar et al., 1993; Ressler et al., 1994; Mombaerts et al., 1996). Specific odors activate several cohorts of receptor neurons that generate a specific pattern of glomerular activation (Meredith, 1986; Johnson et al., 1998; Rubin and Katz, 1999). If LLDs are present in vivo, they could amplify weak olfactory inputs to a mitral cell by producing a prolonged excitatory response. Our findings indicate that this prolonged excitation will engage many, if not all, of the M/T cells associated with the same glomerulus. Therefore, by "binding" the activity of $\mathrm{M} / \mathrm{T}$ cells associated with the same glomerulus, LLDs may be involved in maintaining the spatiotemporal patterns of odor-induced glomerular activity at higher levels of the olfactory system.

LLDs exhibit a long refractory period (Figs. 5, 6). A similar refractory period $(\sim 1 \mathrm{sec})$ after odor-evoked activity occurs in vivo (Ottoson, 1959; Scott, 1977; Orbach and Cohen, 1983) and in the isolated turtle olfactory bulb (Mori et al., 1981). Because the refectory period after an LLD is significantly longer than the 4-7 Hz "sniff cycle" (Adrian, 1950; Freeman, 1972), LLDs are probably not entrained during sniffing. However, the refractory period after an LLD may influence odor discrimination.

For example, suppose an odor presented during the first sniff in a cycle produced LLDs in a subset of M/T cells. In the next sniff those neurons would be refractory and thus would not generate an LLD. However, a new odor would activate LLDs in another set of neurons, associated with a different glomerulus. Thus, LLDs could enhance the detection of changes in olfactory input from one sniff to the next.

\section{REFERENCES}

Adrian ED (1950) Sensory discrimination with some recent evidence from olfactory tract. Br Med Bull 6:330-333.

Allison AC, Warwick TT (1949) Quantative observations on the olfactory system of the rabbit. Brain 72:186-197.

Aroniadou-Anderjaska V, Ennis M, Shipley MT (1999a) Current-source density analysis in the rat olfactory bulb: laminar distribution of kainate/AMPA- and NMDA-receptor-mediated currents. J Neurophysiol 81:15-28.

Aroniadou-Anderjaska V, Ennis M, Shipley MT (1999b) Dendrodendritic recurrent excitation in mitral cells of the rat olfactory bulb. J Neurophysiol 82:489-494.

Bardoni R, Magherini PC, Belluzzi O (1996) Excitatory synapses in the glomerular triad of frog olfactory bulb in vitro. NeuroReport 7:1851-1855.

Bergles DE, Diamond JS, Jahr CE (1999) Clearance of glutamate inside the synapse and beyond. Curr Opin Neurobiol 9:293-298.

Berry MS, Pentreath VW (1976) Criteria for distinguishing between monosynaptic and polysynaptic transmission. Brain Res 105:1-20.

Beuerman RW (1975) Slow potentials of the turtle olfactory bulb in response to odor stimulation of the nose. Brain Res 97:61-78.

Buonviso N, Chaput MA, Scott JW (1991) Mitral cell-to-glomerulus connectivity: an HRP study of the orientation of mitral cell apical dendrites. J Comp Neurol 307:57-64.

Cajal SR (1995) Histology of the nervous system. New York: Oxford UP.

Carlson GC, Heyward P, Ennis M, Shipley MT, Keller A (1997) Active membrane properties in mitral cells of the rat olfactory bulb. Soc Neurosci Abstr 23:1268.

Chen WR, Shepherd GM (1997) Membrane and synaptic properties of mitral cells in slices of rat olfactory bulb. Brain Res 745:189-196.

Chen WR, Midtgaard J, Shepherd GM (1997) Forward and backward propagation of dendritic impulses and their synaptic control in mitral cells. Science 278:463-467.

Cheramy A, Leviel V, Glowinski J (1981) Dendritic release of dopamine in the substantia nigra. Nature 289:537-542.

Cinelli AR, Salzberg BM (1992) Dendritic origin of late events in optical recordings from salamander olfactory bulb. J Neurophysiol 68:786-806.

Cinelli AR, Hamilton KA, Kauer JS (1995) Salamander olfactory bulb neuronal activity observed by video rate, voltage-sensitive dye imaging. III. spatial and temporal properties of responses evoked by odorant stimulation. J Neurophysiol 73:2053-2071.

Crépel V, Aniksztejn L, Ben-Ari Y, Hammond C (1994) Glutamate metabotropic receptors increase a $\mathrm{Ca}^{2+}$-activated nonspecific cationic current in CA1 hippocampal neurons. J Neurophysiol 72:1561-1569.

Ennis M, Zimmer LA, Shipley MT (1996) Olfactory nerve stimulation activates rat mitral cells via NMDA and non-NMDA receptors in vitro. NeuroReport 7:989-992.

Freeman WJ (1972) Measurement of oscillatory responses to electrical stimulation in olfactory bulb of cat. J Neurosci 35:762-779.

Gil Z, Amitai Y (1996) Properties of convergent thalamocortical and intracortical synaptic potentials in single neurons of neocortex. J Neurosci 16:6567-6578.

Glitsch M, Llano I, Marty A (1996) Glutamate as a candidate retrograde messenger at interneuron-Purkinje cell synapses of rat cerebellum. J Physiol (Lond) 497:531-537.

Gottlieb JP, Keller A (1997) Intrinsic circuitry and physiological properties of pyramidal neurons in rat barrel cortex. Exp Brain Res 115:47-60.

Greene CC, Schwindt PC, Crill WE (1994) Properties and ionic mechanisms of a metabotropic glutamate receptor-mediated slow afterdepolarization in neocortical neurons. J Neurophysiol 72:693-704.

Haberly LB, Sutula TP (1992) Neuronal processes that underlie expression of kindled epileptiform events in the piriform cortex in vivo. J Neurosci 12:2211-2224.

Heyward PM, Tian Y, Shipley MT (1999) Electrophysiology of identified mitral and tufted cells in the main olfactory bulb. Achem S XXI:148.

Isaacson JS (1999) Glutamate spillover mediates excitatory transmission in the rat olfactory bulb. Neuron 23:377-384.

Isaacson JS, Strowbridge BW (1998) Olfactory reciprocal synapses: dendritic signaling in the CNS. Neuron 20:749-761.

Jahr CE, Nicoll RA (1980) Dendrodendritic inhibition: demonstration with intercellular recording. Science 207:1473-1475.

Johnson BA, Woo CC, Leon M (1998) Spatial coding of odorant features in the glomerular layer of the rat olfactory bulb. J Comp Neurol 393:457-471.

Kasowski HJ, Kim H, Greer CA (1999) Compartmental organization of the olfactory bulb glomerulus. J Comp Neurol 407:261-274.

Keller A, Yagodin S, Aroniadou-Anderjaska V, Zimmer LA, Ennis M, Sheppard NF, Shipley MT (1998) Synaptic physiology of rat olfactory bulb glomeruli revealed by optical imaging. J Neurosci 18:2602-2612.

Kosaka K, Toida K, Margolis FL, Kosaka T (1997) Chemically defined neuron groups and their subpopulations in the glomerular layer of the rat main olfactory bulb. II. Prominent differences in the intraglomerular dendritic arborization and their relationship to olfactory nerve terminals. Neuroscience 76:775-786.

Meisami E, Safari L (1981) A quantitative study of the effects of early unilateral olfactory deprivation on the number and distribution of mitral and tufted cells and of glomeruli in the rat olfactory bulb. Brain Res 221:81-107.

Meredith M (1986) Patterned response to odor in mammalian olfactory bulb: the influence of intensity. J Neurophysiol 56:572-597.

Mombaerts P, Wang F, Dulac C, Chao SK, Nemes A, Mendelsohn M, Edmondson J, Axel R (1996) Visualizing an olfactory sensory map. Cell 87:675-686.

Montague AA, Greer CA (1999) Differential distribution of ionotropic 
glutamate receptor subunits in the rat olfactory bulb. J Comp Neurol 405:233-246.

Mori K, Takagi SF (1975) Spike generation in the mitral cell dendrite of the rabbit olfactory bulb revealed bulb. Brain Res 100:685-689.

Mori K, Nowycky M, Shepherd GM (1981) Synaptic excitatory and inhibitory interactions at distal dendritic sites of mitral cells in the isolated turtle olfactory bulb. J Neurosci 4:2291-2296.

Morishita W, Kirov SA, Alger BE (1998) Evidence for metabotropic glutamate receptor activation in the induction of depolarizationinduced suppression of inhibition in hippocampal CA1. J Neurosci 18:4870-4882.

Nickell WT, Behbehani MM, Shipley MT (1994) Evidence for GABA ${ }^{-}$ mediated inhibition of transmission from the olfactory nerve to mitral cells in the rat olfactory bulb. Brain Res Bull 35:119-123.

Nickell WT, Shipley MT, Behbehani MM (1996) Orthodromic synaptic activation of rat olfactory bulb mitral cells in isolated slices. Brain Res Bull 39:57-62.

Nicoll RA (1971) Pharmacological evidence for GABA as the transmitter in granule cell inhibition in the olfactory bulb. Brain Res $35: 137-149$.

Nicoll RA, Jahr CE (1982) Self-excitation of olfactory bulb neurons. Nature 296:441-444.

Nowycky CM, Mori K, Shepherd GM (1981) Blockade of synaptic inhibition reveals long-lasting synaptic excitation in isolated turtle olfactory bulb. J Neurophysiol 46:649-657.

Orbach HS, Cohen LB (1983) Optical monitoring of activity from many areas of the in vitro and in vivo salamander olfactory bulb: a new method for studying functional organization in the vertebrate central nervous system. J Neurosci 3:2251-2262.

Ottoson D (1956) Studies on slow potentials in the rat rabbit olfactory bulb and nasal mucosa. Acta Physiol Scand 47:136-148.

Ottoson D (1959) Olfactory bulb potentials induced by electrical stimulation of the nasal mucosa of the frog. Acta Physiol Scand 47:160-172.

Paternain AV, Vicente MA, Nielsen E, Lerma J (1996) Comparative antagonism of kainate-activated AMPA and kainate receptors in hippocampal neurons. Eur J Neurosci 8:2129-2136.

Pinching AJ, Powell TPS (1971) The neuropil of the glomeruli of the olfactory bulb. J Cell Sci 9:347-377.
Pitler TA, Alger BE (1990) Activation of the pharmacologically defined M3 muscarinic receptor depolarizes hippocampal pyramidal cells. Brain Res 234:257-262.

Price JL, Powell TPS (1970) The mitral and short axon cells of the olfactory bulb. J Cell Sci 7:631-691.

Rall W, Shepherd GW, Reese TS, Brightman MW (1966) Dendrodendritic synaptic pathway for inhibition in the olfactory bulb. Exp Neurol 14:44-56.

Ressler KJ, Sullivan SL, Buck LB (1994) Information coding in the olfactory system: Evidence for a stereotypical and highly organized epitope map in the olfactory bulb. Cell 79:1245-1255.

Rubin BD, Katz LC (1999) Optical imaging of odorant representations in the mammalian olfactory bulb. Neuron 23:499-511.

Schoppa NE, Kinzie JM, Sahara Y, Segerson TP, Westbrook GL (1998) Dendrodendritic inhibition in the olfactory bulb is driven by NMDA receptors. J Neurosci 18:6790-6802.

Scott JW (1977) A measure of extracellular unit responses to repeated stimulation applied to observations of the time course of olfactory responses. Brain Res 132:247-258.

Shepherd GM (1972) Synaptic organization of the mammalian olfactory bulb. Physiol Rev 52:864-917.

Shepherd GM (1991) Computational structure of the olfactory system. In: Olfaction (Davis JL, Eichenbaum H, eds), pp 3-41. Cambridge, MA: MIT

Shipley MT, Ennis M (1996) Functional organization of olfactory system. J Neurobiol 30:123-176.

Traub RD, Wong RK (1982) Cellular mechanisms of neuronal synchronization in epilepsy. Science 239:1147-1150.

Trombley PQ, Westbrook GL (1990) Excitatory synaptic transmission in cultures of rat olfactory bulb. J Neurophysiol 64:598-606.

Vassar R, Ngai J, Axel R (1993) Spatial segregation of odorant receptor expression in the mammalian olfactory epithelium. Cell 74:309-318.

Vignes M, Bleakman D, Lodge D, Collingridge GL (1997) The synaptic activation of the GluR5 subtype of kainate receptor in area CA3 of the rat hippocampus. Neuropharmacology 36:1477-1481.

White EL (1973) Synaptic organization of the mammalian olfactory glomerulus: new findings including an interspecies variation. Brain Res 40:299-313. 